\title{
Systematization of theory and methodology for teaching advertising and portrait photography based on the Russian experience
}

\author{
Yuliya Dorofeeva ${ }^{1}$, Aleksey Moiseev ${ }^{1, *}$ \\ ${ }^{1}$ Moscow Region State University, 10A, Radio str., 105005, Moscow, Russia
}

\begin{abstract}
This article aims at systematizing the key methods, principles, and approaches that underlie the proprietary integrated methodology for teaching advertising and portrait photography. Summarizing the authors' wealth of educational expertise and successful experiments in teaching photography in Russia has become the primary objective of this article. The main research methods we employed were as follows: comparative analysis and pedagogical experiment (ascertaining, searching, educational). Findings: Essential aspects of the proprietary integrated methods of teaching advertising and portrait photography have been described; the global and domestic experience of teaching photography has been summarized. The proprietary integrated methods for teaching advertising and portrait photography has been tested by the authors in the systems of higher education, secondary vocational education, and continuing professional education in various fields and areas: design, computer graphics, art photography / photo art, the history, theory, techniques, and technology of photography, including advertising and portrait photography. The following institutions have become the main testing platforms: GOU VO MO Moscow State Regional University, the Arts and Design School under ANO VO Business and Design Institute, the School of ANOO VO Russian University of Cooperation under the Central Union of Consumer Societies of the Russian Federation (Centrosoyuz of Russia). The article suggests a classification of the aspects essential for advertising and portrait photography, provides recommendations for how to teach these types of photography, along with featuring the statistics on successful/failed students' assignments and providing examples of copyrighted photographs taken for magazines.
\end{abstract}

\section{Introduction}

This article aims at systematizing the key methods, principles, and approaches that underlie the proprietary integrated methodology for teaching advertising and portrait photography set forth herein. Summarizing the authors' wealth of educational expertise and

\footnotetext{
${ }^{*}$ Corresponding author: moiseev arthouse@mail.ru
} 
successful experiments in teaching photography in universities, secondary vocational and continuing education institutions in Russia, as well as many years of experience in advertising and portrait photography has become the primary objective of this article. The urgency of systematizing the key methods, principles, and approaches that form the integrated methodology for teaching advertising and portrait photography in universities, secondary vocational and continuing education systems, in our opinion, is poorly disclosed in the foreign and domestic scientific literature available, as indicated by the shortage of strong textbooks and teaching guides in this area required by the latest Federal State Educational Standards of Higher Education and Secondary Vocational Education and Federal Government Requirements. Though this issue is of relevance and importance, the degree of its scientific maturity is relatively low, which is a key contradiction that underlies the range of problems under study.

Nonetheless, methodological and copyright developments of the applied nature (selfstudy and teaching guides, manuals, etc.) are quite numerous in the field of photography. We can cite books on various aspects of feature photography authored by both domestic and foreign authors: Alexander Lapin, Michael Freeman, Tracey Clark, Pavel Kosenko, Joe McNally, Michelle Turner, Scott Kelby, William Mortensen, Michael Frye, Lee Frost, Robert Thompson, and many others. Active expert communities, workshops, photo courses, photo schools, magazines, up-to-date Internet resources - the field of photography has all of these, yet, due to the extremely dynamic development of this field, educational, methodological, and scientific materials quickly lose their relevance for practical application.

\section{Materials and Methods}

The key research methods are as follows: Theoretical - analyzing philosophical, historical, art history, psychological, educational, and methodological literature; studying regulatory and legislative documents; analyzing personal educational and creative experience; empirical - pedagogical observation, selecting and developing teaching methods; surveys, quizzes, questionnaires, pedagogical experiments; studying and analyzing creative activities of students; summarizing deliverables; experimental work.

Depending on the educational background, approaches to teaching advertising and portrait photography, as a rule, can slightly vary: to a greater extent, changes center around the requirements to the quality and volume of educational and creative assignments for students and their component focused on developing practical skills as part of a specific educational program. Next, we will consider the key methods, principles, and approaches that underlie the authors' proven integrated methodology for teaching advertising and portrait photography.

\section{The Key Features of Advertising and Portrait Photography}

Please, find below our own classification of advertising photography, which includes the following main blocks:

1. Product shooting / still life advertising photography

- $\quad$ Food photography (menus, dishes, food, drinks)

- Cosmetics photography

- Accessories photography (shoes, bags, gloves, hats)

- Jewelry photography

2. Advertising portrait photography.

3 Advertising photography for banners, media advertising 
4 Advertising photography for stock image banks

5. Advertising photos of animals and their use for brand advertising

6. Social advertising

7. Advertising shooting of interiors, landscapes, architecture

8. Advertising campaigns featuring products created using photos (without limitation)

9. Digital art

10. B2B advertising

The classification of portrait photography consists of the following main blocks:

1. True-to-life portrait / character-revealing portrait

2. Scenic portrait / life-style portrait

3. Classical portrait

4. Wedding portrait, family photography, collective portrait

5. Business portrait / image-building photography / full-dress portrait

6. Children's portrait / shooting of children

7. Group portrait

8. Art portrait photography incorporating various thematic stylizations (for example, fairy-tale style, archaization, pastiche of art movements or trends)

9. Beauty portrait.

10. Advertising portrait

11. Art nude portrait - portraits of fully or partially naked people

12. Portrait with animals

13. Celebrity portrait / secular photography, glamour photography

14. Fashion portrait Genre classification:

- Model tests;

- Catalog photography;

- Lookbooks or editorials for fashion designers;

- Campaigns.

15. Art-fashion portrait (sharing tasks of art and fashion photography)

16. Model tests, snapshots and other types of applied photography

\section{Results}

We have conducted an educational experiment on students of three universities over the period of 2007 to 2020 , with $250+$ participants involved. Some of them are successful photographers now, acting in the field of advertising, design, and fashion. Some have been awarded certificates of professional recognition. The average success level achieved by students in the performance of educational and creative assignments, based on the statistical data of the Department of Fine Arts and Folk Crafts of GOU VO MO Moscow State Regional University, the Arts and Design School under ANO VO Business and Design Institute, the School of ANOO VO Russian University of Cooperation under the Centrosoyuz of Russia received in the course of studying Graphic Photography, Photo Art, Organization of Exhibitions (Photography), Technique and Technology of Advertising Photography and the statistical data of the system of continuing professional education during photo lessons at the Institute for Open Education, Moscow Region State University, based on proprietary methods, was approximately the same, and made it possible to define the easiest and most difficult assignments for students to complete.

1. Outdoor life-style portrait in natural lighting - on average, successfully completed by approximately 89 percent of students

2. True-to-life portrait/classical/character-revealing/scenic portrait - on average, successfully completed by approximately 78 percent of students 
3. Full-size fashion portrait - on average, successfully completed by approximately 63 percent

4. Stylized art portrait - on average, successfully completed by approximately 70 percent

5. Beauty portrait with editorial retouching - on average, successfully completed by approximately 47 percent

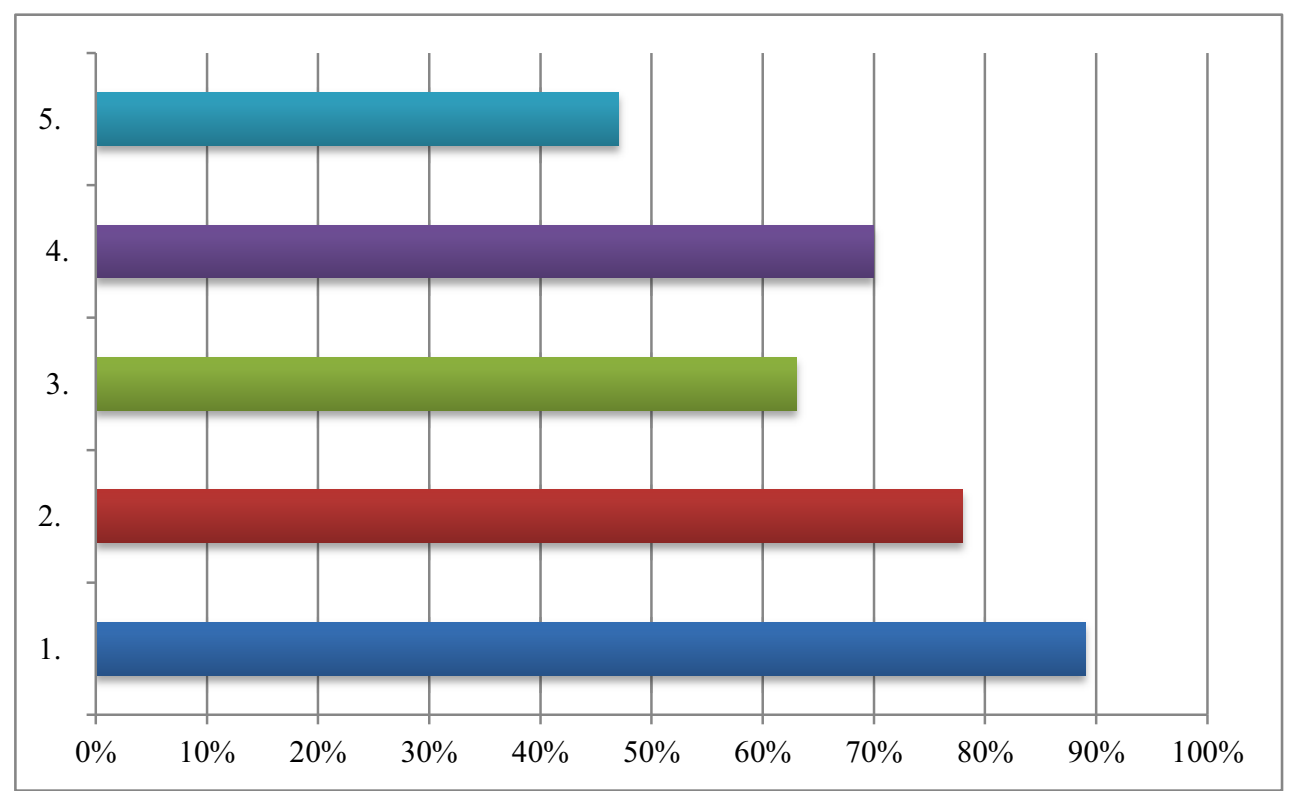

Fig. 1. Students' success in completing assignments depending on specifics.

During our experimental work, we have developed active and interactive forms of holding advertising and portrait photography classes, thus encouraging students to be more motivated, dedicated to the learning process; we have made use of information and communication technology, study aids and online consulting. Our assignments contained numerous interdisciplinary references to composition, color science and coloristics, exposure technology, graphic photography, photo art, multimedia technology, and computer graphics. Our assignments and exercises clearly demonstrated to the students the possible ways to achieve image-bearing expressiveness and make creative ideas come true.

Describing the components of the proven integrated methodology and summarizing the global and domestic experience in teaching photography have become the deliverables of the study. The matter-of-fact significance also refers to a number of scientific articles and teaching materials written by the authors for universities, secondary vocational and continuing professional institutions in the field of design, computer graphics, feature photography / photo art, history, theory, engineering and technology of photography, including, without limitation, landscape photography. We treat the findings of the study and the key elements of the methodology quite extensively. They can be used to improve the theory and methodology of teaching feature photography in the system of art and creative education, as well as design education.

Also, the authors' work in the fields of advertising and portrait photography have resulted in cooperation with well-known brands, magazines, stylists, makeup artists, and creative teams. In particular, with such internationally recognized foreign and Russian makeup artists as Nick Lujan, Alex Box, Loni Baur, Christian Schild, Andrey Shilkov, Denis Kartashov, Anna Priadka, Olga Romanova, Anna Kartashova, etc. 
The specifics of working with images, lighting, retouching, models, various creative approaches and other aspects of our integrated methodology for teaching advertising and portrait photography can be seen in examples of copyright works published in famous international and Russia-based magazines: Vogue Italia, MOD Magazine , Ellements Magazine, IMIRAGEmagazine, LUCY'S Magazine, KALTBLUT Magazine, Marie Claire Russia, Scorpio Jin Magazine, VOLANT Magazine, MuaClub, Cherry Magazine, Elegant Magazine, VGXW Magazine by Virtuogenix, IntElegance Magazine, DREAMINGLESS, WD Magazine, JUTE Magazine, C'est Moi Magazine, The Community Arts Magazine, Cabinet de l'art Virtue Magazine, Magazine DAZ, The Community Arts Magazine, etc.

Above all, as our achievements in teaching advertising and portrait photography, we cite the experience of collaboration with global and domestic brands such as: DIOR, Cle de peau beaute, Shiseido, M.A.C., Kevyn Aucoin, Nouba, NARS, Stellary cosmetics, Manly Pro, SORME, PAESE, Miobrush, TF cosmetics, etc.

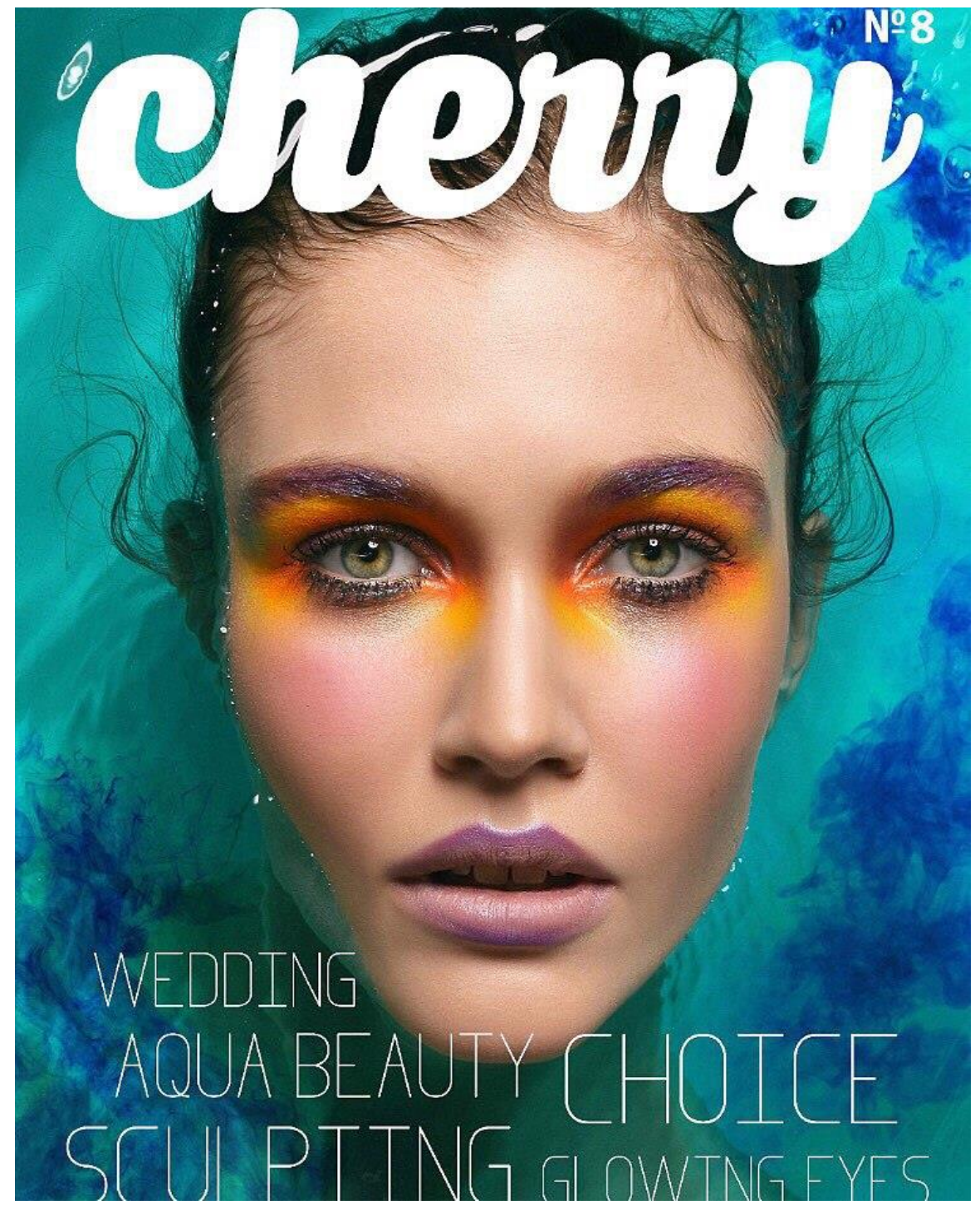

Fig. 2. Yuliya Dorofeeva. Cherry Magazine cover. 


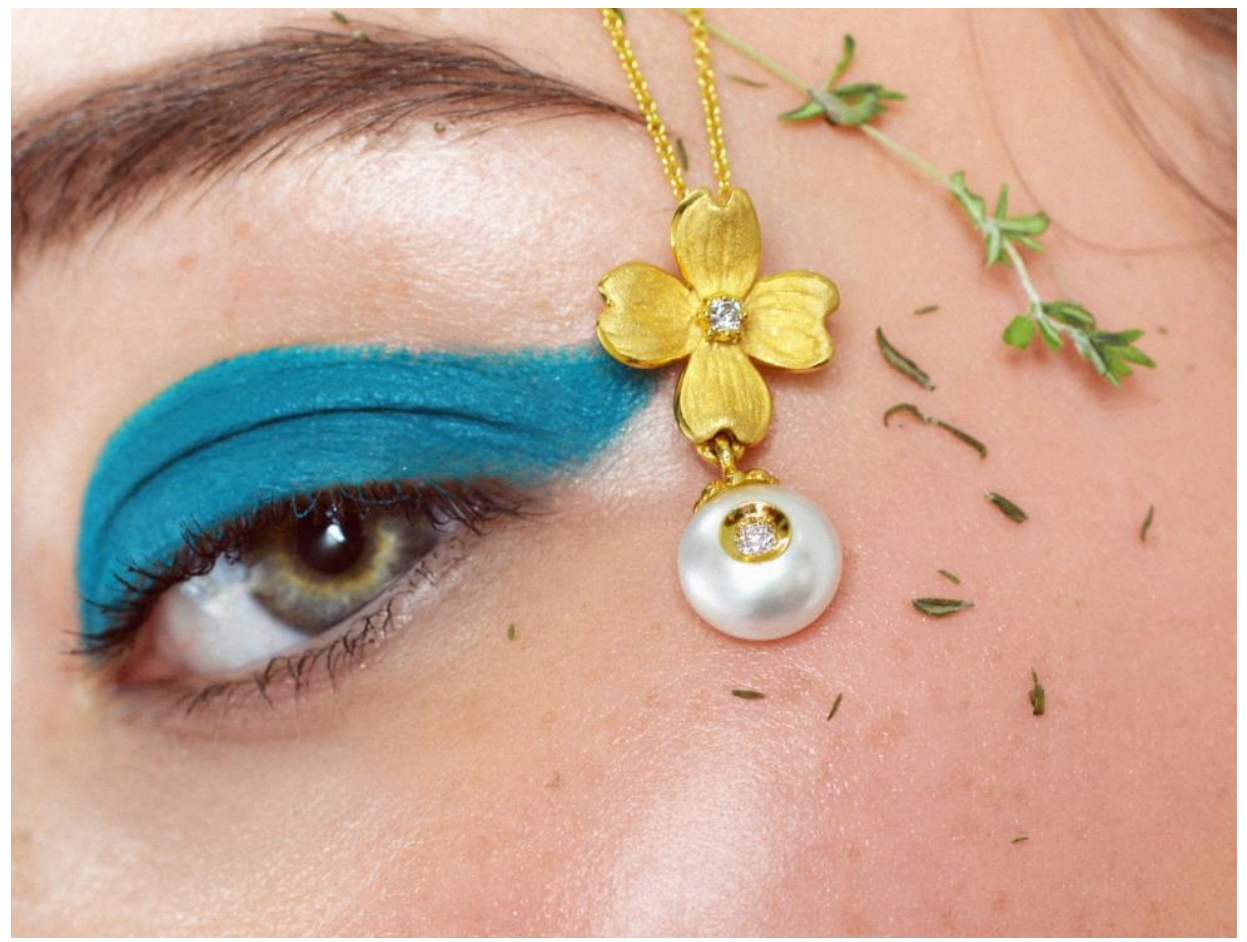

Fig. 3. Yuliya Dorofeeva. Examples of close-ups in advertising beauty portrait.

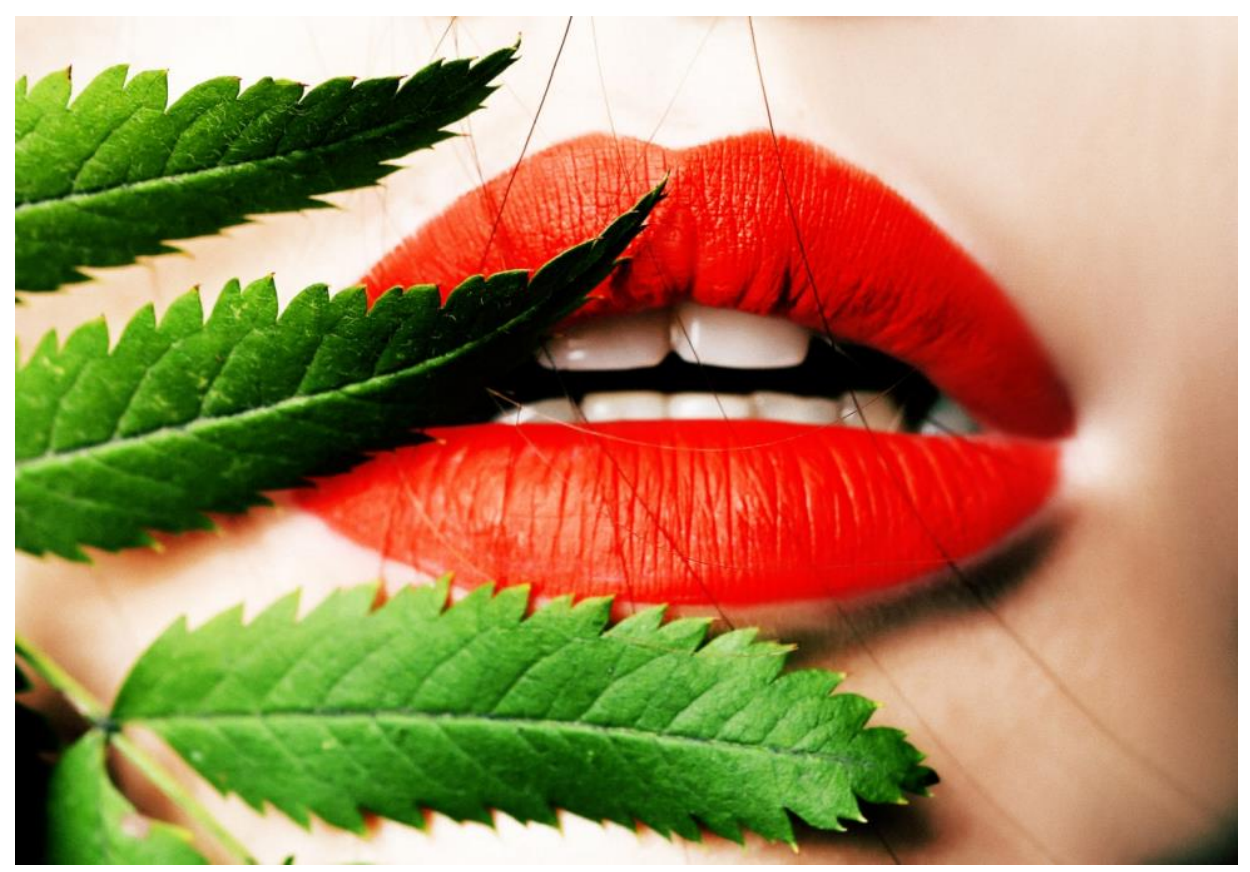

Fig. 4. Yuliya Dorofeeva. Examples of close-ups in advertising beauty portrait. 


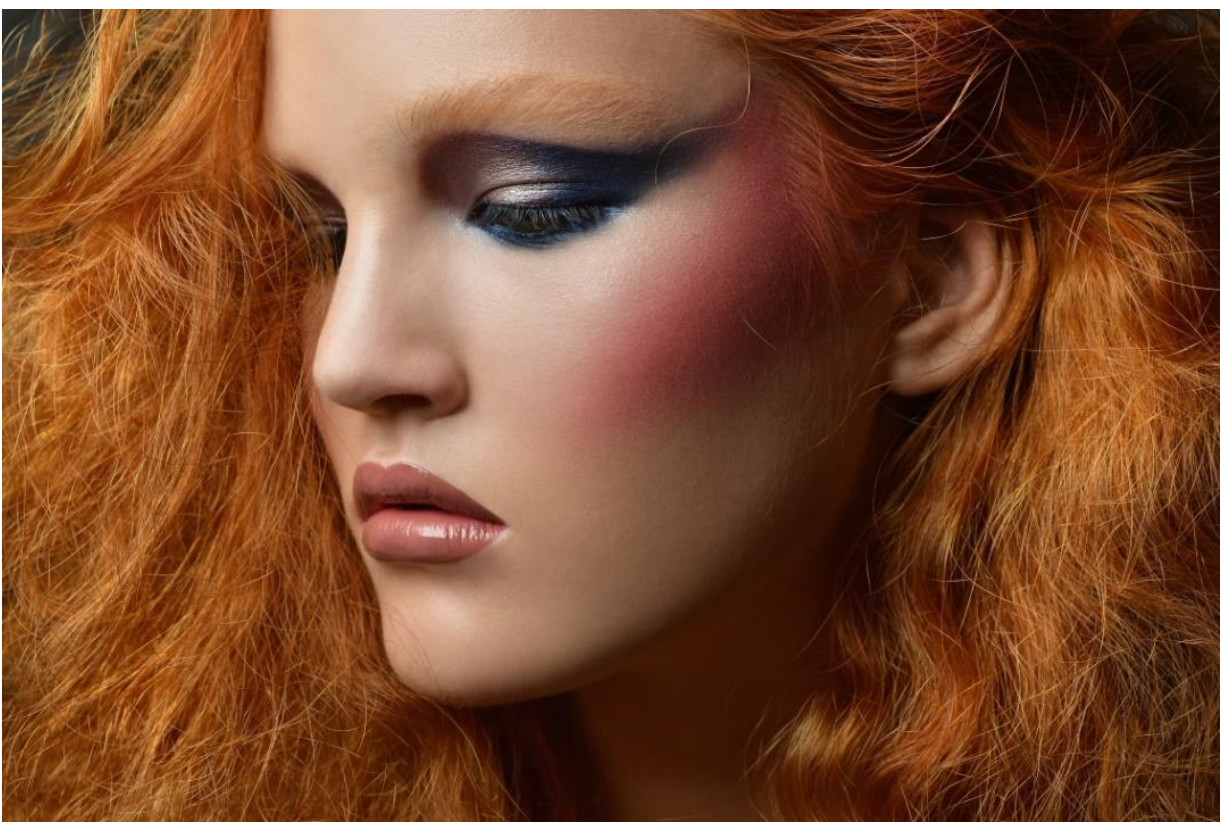

Fig. 5. Yuliya Dorofeeva. Examples of creative approaches in advertising beauty portrait.

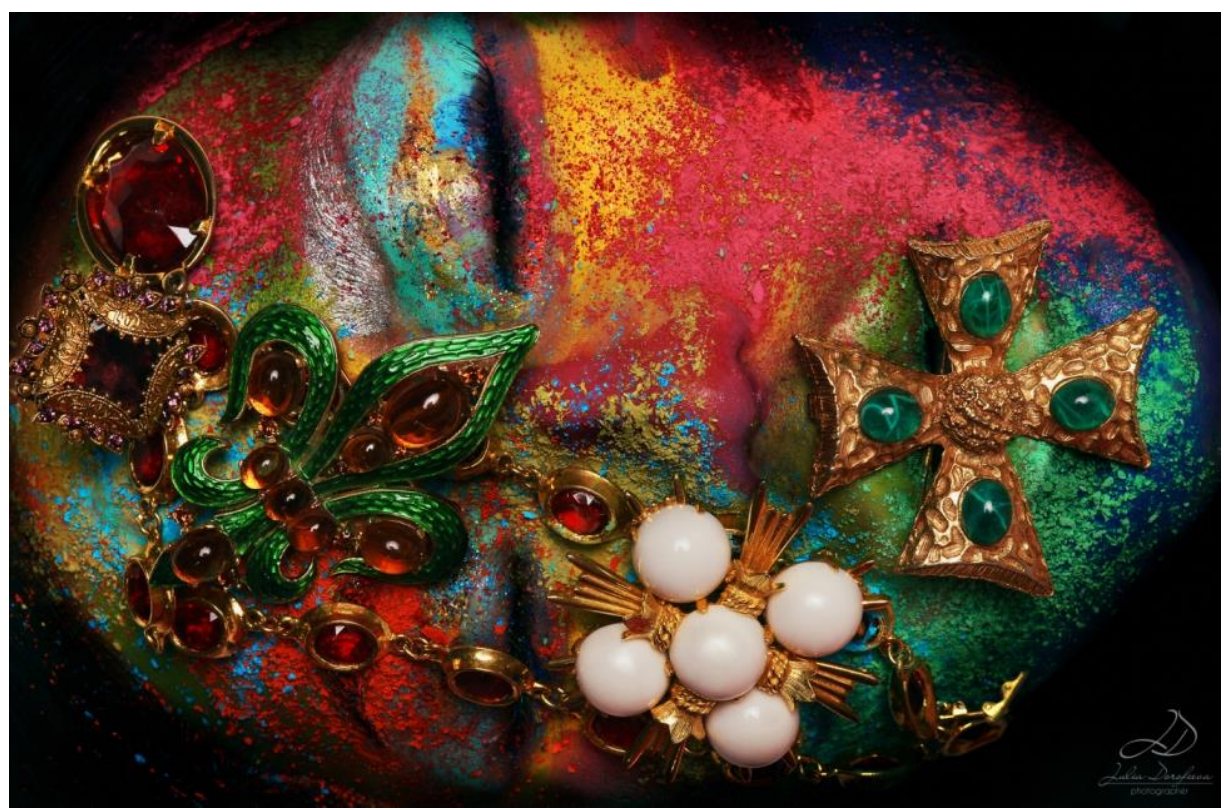

Fig. 6. Yuliya Dorofeeva. Examples of creative approaches in advertising beauty portrait. 


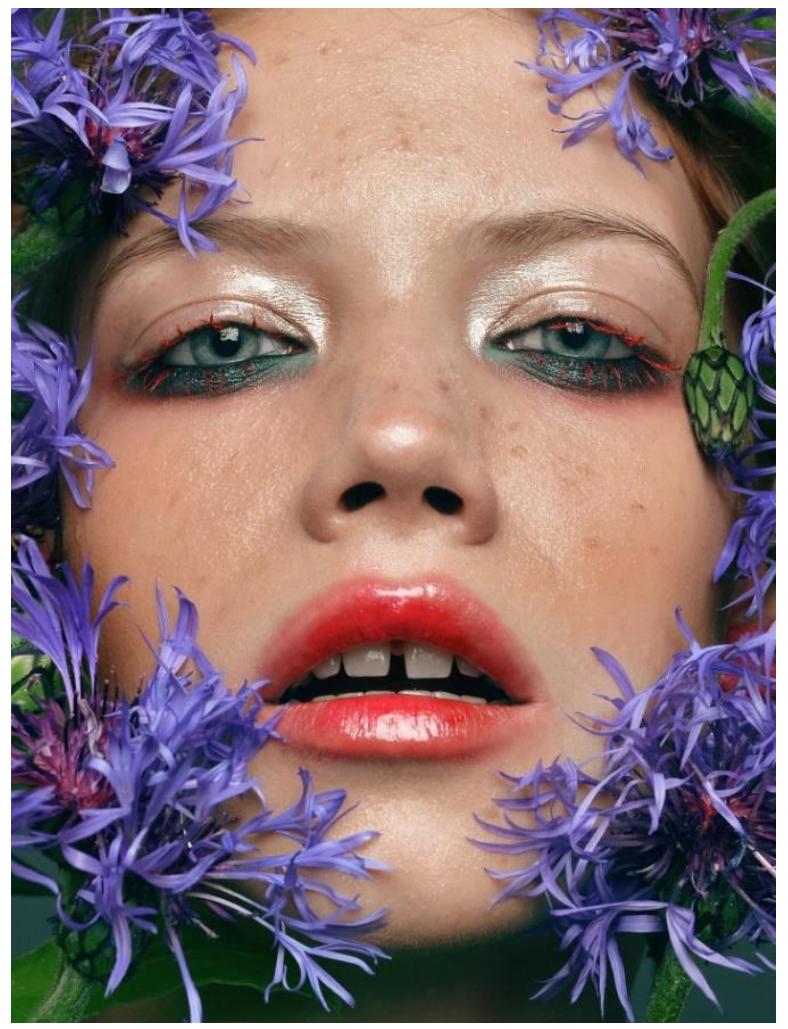

Fig. 7. Yuliya Dorofeeva. Using the "eye to eye" technique and luminous effects in photographic processing.

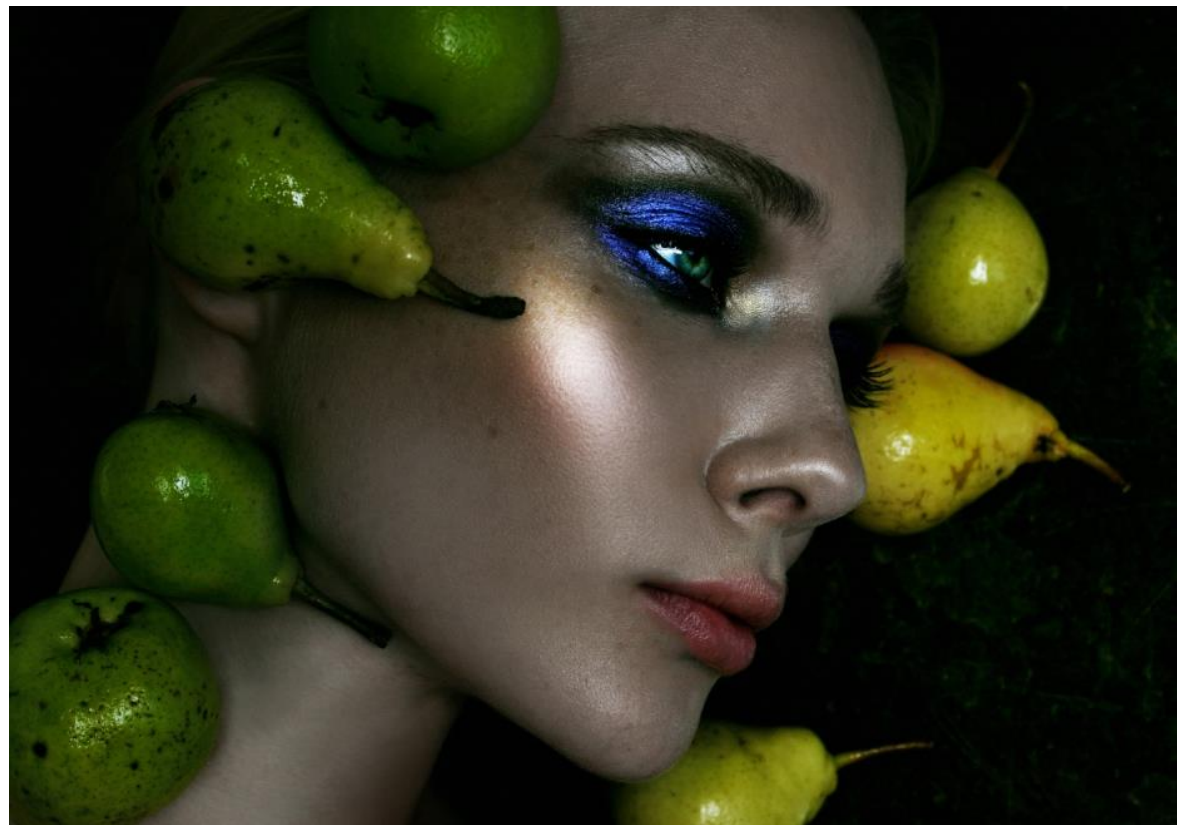

Fig. 8. Yuliya Dorofeeva. Using the "eye to eye" technique and luminous effects in photographic processing. 


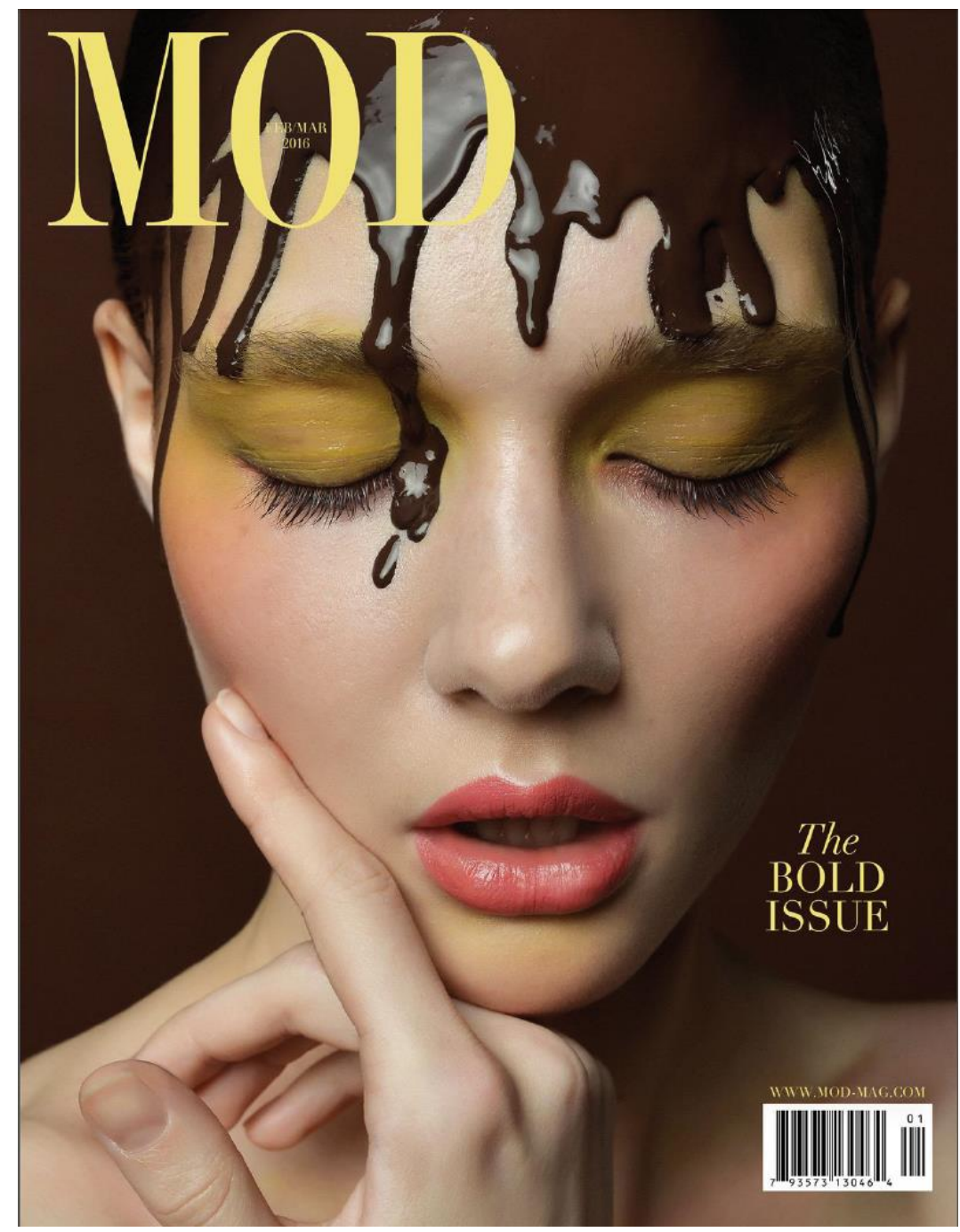

Fig. 9. Yuliya Dorofeeva. MOD Magazine cover.

\section{Discussion}

In the above described proprietary integrated methodology for teaching advertising and portrait photography we are describing, the experience of schools of thought and research in the field of art, pedagogical, and design education has been generalized. As a result, we consider the scientific works of R. Bartsits [2], S. Ye. Ignatiev, V.V Koreshkov, V.S Kuzin, S.P. Lomov [6, 7], N.N. Rostovtsev, V.F. Runge [12], D.A. Khvorostov [14], P.D. Chistov [7, 14], Ye. V. Shorokhov as fundamental for the modern educational system of Russia. The historical, theoretical, and practical aspects of teaching photography that have contributed to shaping our integrated methodology are covered by Ye.V. Barkhatova, A.S. Vartanov, A.Yu. Kravtsova, S. V. Kulagin, A.I. Lapin, A.B. Meledin, M.K. Musorin, M. Oland, S.G. Pozharskaya, G.K. Pondopulo, A.V. Redko, G.D. Rozov, A.V. Ruzaev, N.M. Solovieva, V.T. Stigneev, L. Frost, N.A. Khrenov, Y.A. Yakimovich, and others in their works. 
The integrated methodology is also based on experiments and practical, creative, and educational experience of such canonical art photographers as Robert Adamson,Frederick Scott Archer, Louis-Auguste Bisson, Auguste-Rosalie Bisson, Felix Beato, Louis Désiré Blanquart-Evrard, Karl Blossfeldt, Mathew Brady, Carl Oswald Bulla, Louis Jacques Mandé Daguerre, Philip Johnson, George Eastman, Henri Cartier-Bresson, James Ambrose Cutting, Julia Margaret Cameron, Anna-Lou "Annie" Leibovitz, Louis Lumiere, Auguste Lumiere, Steve McCurry, Samuel Morse, William Notman, Joseph Nicéphore Niépce, S.M. Prokudin-Gorsky, Oscar Gustave Rejlander, Henry Peach Robinson, Josef Sudek, William Henry Fox Talbot, Gaspard-Félix Tournachon (Nadar), Roger Fenton, David Octavius Hill, Edward Steichen, Alfred Stieglitz, Anna Atkins, etc.

\section{Conclusions}

It can be concluded that photography (including photo art, graphic photography, and similar disciplines) as an educational discipline in terms of the Federal State Educational Standards of Higher Education and Secondary Vocational Education and Federal State Requirements of the Russian Federation is spread significantly less than the role assigned thereto in today's society suggests. As a result, students have an immature attitude to photography as an element of fine arts and world art culture and there is no professional system of feature photography concepts and ideas available (outstanding representatives and their photo art works, competitions and exhibition platforms, etc.). In the today's environment oversaturated with photographs and visual images, it is virtually impossible for a student to navigate and tell the important from the unessential, the quality from the mediocre, and, sometimes, the destructive.

Teaching feature photography and photo art in Russia is sometimes scattered and haphazard in nature and is given less importance amidst global trends. As there is no opportunity to obtain a university degree in photography and photo art, and against the background of weak professional education and the obsolescence of educational techniques, the bulk of educational activities is organized within the system of continuing education in the form of courses, photo schools, workshops and individual classes.

In conclusion, we should mention that the art of feature photography in the form it exists in the modern system of higher, secondary vocational continuing professional education has strong untapped potential in terms of teaching students imaginative thinking and making creative, art, and design activities more intense. Our research has helped systematize the key methods, principles, and approaches that underlie the proprietary integrated methodology for teaching advertising and portrait photography. The study has identified a number of opportunities to make students more involved in creative activities by means of feature photography; the scientific and theoretical principles of teaching feature photography in the context of modern art education in Russia have been substantiated; the educational experience gained in the development of world and Russian art of feature photography has been generalized and systematized; the method of making students more involved in creative activities by means of advertising and portrait photography has proven effective. In the course of the study, effective forms and methods of and methodological techniques for teaching students advertising and portrait photography have been identified.

\section{Acknowledgements}

We would like to express our appreciation to all the organizations that have provided their kind assistance and support in the course of our study; the integrated methodology for 
teaching advertising and portrait photography has been tested at the Department of Fine Arts and Folk Crafts of GOU VO MO Moscow State Regional University, the Arts and Design School under ANO VO Business and Design Institute, the School of ANOO VO Russian University of Cooperation under the Centrosoyuz of Russia while teaching Graphic Photography, Photo Art, Organization of Exhibitions (Photography), Technique and Technology of Advertising Photography and within the system of continuing professional education during photo art lessons at the Institute for Open Education, Moscow Region State University, based on proprietary methods. We would also like to thank the following magazines for their cooperation and the opportunity to publish our photo content: Vogue Italia, Mod Magazine, ellements Magazine, IMIRAGEmagazine, LUCY'S Magazine, KALTBLUT Magazine, Marie Claire Russia, Scorpio Jin Magazine, VOLANT Magazine, MuaClub, Cherry Magazine, Elegant Magazine, VGXW Magazine by Virtuogenix, IntElegance Magazine, DREAMINGLESS, WD Magazine, C'est Moi Magazine, The COMMUNITY arts Magazine, etc.

\section{References}

1. L.Yu. Aphanaskina, S.A. Amanzholov, A.A. Moiseev, The Collection of Scientific Papers of the XIV International Conference and the XII International Competition of Scientific and Methodological Works (Moscow, 2019)

2. R.C. Bartsits, Hot Topics of Art and Aesthetic Education in the Context of Culture and Arts. Proceedings of the International Scientific and Practical Conference (2018)

3. S.V. Demenetyeva, "The Great Steppe and Eurasian Values: Art Education and Aesthetic Education" (in celebration of the 25th anniversary of independence of the Republic of Kazakhstan). Proceedings of the International Scientific and Practical Conference (Astana, Gumilyov Eurasian National University,2017)

4. Yu.Yu. Dorofeefa, Russian Scientific Journal 2(45), 250 (2015)

5. Yu.Yu. Dorofeefa, Proceedings of the Russian Annual Scientific and Practical Conference of Teachers, Postgraduates, and Students "Science, for the Benefit of Mankind 2016," dedicated to the 85th anniversary of Moscow State University (Moscow, 2016)

6. S.P. Lomov, The Ways and Means to Improve the Quality of Art and Aesthetic Education. The Shared Collection of Scientific and Methodological Works of Universities (Moscow, 2018)

7. S.P. Lomov, M.V. Galkina, P.D. Chistov, Art and Education 1(117), 77 (2019)

8. I.A. Lvova, "The Great Steppe and Eurasian Values: Art Education and Aesthetic Education" (in celebration of the 25th anniversary of independence of the Republic of Kazakhstan). Proceedings of the International Scientific and Practical Conference (Astana, Gumilyov Eurasian National University, 2017)

9. N.S. Lvova, Aspects of Shaping Professional Creative Thinking among Students of Design Institutions. Social Identifier: Pedagogical Sciences (Moscow, Editus, 2016)

10. A.A. Moiseev, Yu.Yu. Dorofeeva, "The Great Steppe and Eurasian Values: Art Education and Aesthetic Education" (in celebration of the 25th anniversary of independence of the Republic of Kazakhstan). Proceedings of the International Scientific and Practical Conference (Astana, Gumilyov Eurasian National University, 2017) 
11. A.A. Moiseev, Proceedings of the Russian Annual Scientific and Practical Conference of Teachers, Postgraduates, and Students "Science, for the Benefit of Mankind 2016," dedicated to the 85th anniversary of Moscow State University (Moscow, 2016)

12. V.F. Runge, V.V. Senkovsky, The Baciss of Design Theory and Methodology: Textbook. 3rd ed (M., MZ Press, 2005)

13. B. Hiller, Style of the XX Century: Transl. from Eng (M., SLOVO, 2004)

14. I.B. Bosykh, Designing Competitive Packaging: the Methodological Guide for Teachers in Design and Engineering (Publisher: Architekton, 2014)

15. D.A. Khvorostov, The System of Professional Training of Students of Art and Graphic Design Departments for IT-based Design Activities. Thesis Research... Dr. Sc. Theory of and Methodology for Professional Education (Oryol, 2013)

16. P.D. Chistov, I.Yu. Rudnev, The System Basics of the Fine Arts Teaching Methodology. Law and Practice 2, 232 (2017) 